\title{
The Arming of Europe
}

and the Making of the First World War 



\title{
The Arming of Europe and the \\ Making of the First World War
}

\author{
David G. Herrmann
}

PRINCETON UNIVERSITY PRESS

PRINCETON, NEW JERSEY 
Copyright (C) 1996 by Princeton University Press

Published by Princeton University Press, 41 William Street,

Princeton, New Jersey 08540

In the United Kingdom: Princeton University Press,

Chichester, West Sussex

All Rights Reserved

Library of Congress Cataloging-in-Publication Data

Herrmann, David G. (David Gaius), 1962

The arming of Europe and the making of

the First World War / David G. Herrmann.

p. $\mathrm{cm}$.

Includes bibliographical references and index.

1. World War, 1914-1918-Causes.

2. Arms race-Europe. 3. Military readiness-Europe.

I. Title.

D511.H453 1995 940.3'll—dc20 95-11049 CIP

ISBN 0-69l-3374-9

ISBN 0-691-01595-3 (pbk.)

This book has been composed in Galliard

Princeton University Press books are printed on acid-free paper and meet the guidelines for permanence and durability of the Committee on Production Guidelines for Book Longevity of the Council on Library Resources

Fifth printing, and first paperback printing, with new illustrations, 1997

http://pup.princeton.edu

Printed in the United States of America 
To my parents 
